\title{
Pengaruh Patriotisme, Commitment, dan Caputilation Terhadap Kepatuhan Wajib Pajak Dalam Penyampaian SPT Tahunan Orang Pribadi
}

\author{
Rio Johan Putra \\ Rioacun99@gmail.com \\ Universitas 17 Agustus 1945 Jakarta
}

\begin{abstract}
ABSTRAK
Tujuan penelitian ini adalah untuk mengetahui pengaruh patriotisme, commitment, dan caputilation terhadap kepatuhan wajib pajak orang pribadi dalam melaporkan SPT. Penelitian ini merupakan penelitian kuantitatif dengan menggunakan Partial Least Square (PLS) Penelitian ini menggunakan sampel sebanyak 100 wajib pajak orang pribadi yang memiliki usaha kecil, menengah dan mikro di jakarta utara. Model penelitian ini menggunakan variabel patriotisme dan variabel postur motivasi yang terdiri dari commitment dan capitulation sebagai variabel independen. Model penelitian menunjukkan bahwa partiotisme, commitment, dan capitulation secara parsial berpengaruh positif terhadap kepatuhan wajib pajak orang pribadi dalam menjalankan kewajibannya di bidang perpajakan.

Kata Kunci: Patriotisme, commitment, capitulation, kepatuhan wajib pajak.
\end{abstract}

\section{ABSTRACT}

The purpose of the study was to determine the content of patriotism, commitment, and caputilation of the personal obligations in reporting the tax return. This research is a quantitative research using Partial Least Square (PLS) This study uses a sample of 100 taxpayers of individuals who own small, medium and micro businesses in north jakarta. This research model uses patriotism variable and motivation posture variable consisting of commitment and capitalization as independent variable. The research model shows that partiotism, commitment, and capitation are partial, positive, and negative.

Keywords: Patriotism, commitment, capitulation, tax obligation.

\section{PENDAHULUAN}

Penerimaan pajak di 2017 atau sepanjang 1 Januari hingga 31 Desember 2017 mencapai Rp1.151,10 Triliun. Penerimaan tersebut tercatat 89,68 persen dari target Anggaran Penerimaan dan Belanja Negara Perubahan (APBNP) 2017 yang sebesar Rp1.283,57 Triliun. Pada Tahun 2017 realisasi PPh Final atau pajak UMKM tahun lalu masih jauh dari target yang direncanakan sebesar Rp156,18 Triliun dan hanya dapat terpenuhi sebesar 106,33 Triliun atau hanya 68,08\% dari persentase target (Ditjen Pajak, 2018).

Kesuksesan realisasi penerimaan pajak tidak terlepas dari peran serta wajib pajak. Ketaatan wajib pajak pada ketentuan perpajakan berimplikasi pada rendahnya resiko kecurangan wajib pajak. Iroisnya, Indonesia justru menjadi salah satu negara berkembang dengan tingkat kepatuhan yang rendah. Data menunjukkan bahwa tahun 2016 jumlah wajib pajak yang melaporkan SPT turun dari 20,2 juta di tahun 2015 menjadi 16,5 juta.

Di sisi lain, tidak selamanya wajib pajak akan patuh dalam memenuhi kewajiban perpajakannya, dalam hal ini kepatuhan formal dalam melaporkan SPT Tahunan. Hal ini tergambar pada rasio kepatuhan wajib pajak yang menginformasikan mengenai kepatuhan wajib apajak dalam melaporkan SPT Tahunan Pajak Penghasilan tahun 2016. Rasio kepatuhan wajib pajak secara total, baik wajib pajak orang pribadi maupun wajib pajak badan tercatat hanya $58 \%$ yang artinya jumlah wajib pajak yang patuh melaporkan SPT Tahunan hanya 58\% dari wajib pajak terdaftar (Direktorat Jenderal Pajak, 2017).

Faktor penentu kepatuhan wajib pajak sangat bervariatif, tidak hanya terbatas pada faktor eksternal seperti pengaruh sanksi dan audit perpajakan, namun juga faktor psikologis dan sosial seperti patriotisme. Sebelum zaman kemerdekaan, patriotisme dimaknai sebagai upaya melawan penjajahan. Patriotisme menumbuhkan keterikatan antar bangsa dengan warga negaranya yang ditandai dengan kecintaan seseorang terhadap bangsa dan kebanggaan terhadap identitas nasionalnya (Feshbach 1994 dalam Figueredo and Elkins. 2002). Rela berkoFban demi kepentingan negara merupakan wujud dari rasa patriotisme.

Tingkat patriotisme seseorang dipengauhi oleh kebijakan pemerintah (Konrad and Qari, 2009) Hasil dari kebijakan pemerintah dapat dilihat dari kinerja politik, ekonomi, sosial, hukum, ilmu pengetahuan dan teknologi. Belum Optimalnya kinerja pemerintahan di berbagai bidang tersebut dapat mempengaruhi kepuasan masyarakat terhadap kebijakan pemerintah. Hal tersebut akan menurunkan partisipasi masyarakat dalam memenuhi kewajiban perpajakannya.

Motivasi juga merupakan faktor yang mempengaruhi kepatuhan pajak. Hasil penelitian yang dilakukan oleh Alm (2013), menyebutkan bahwa keputusan kepatuhan wajib pajak dipengaruhi utilitas yang akan diperoleh dengan adanya insentif keuangan. Insentif keuangan dibentuk oleh sanksi dan denda perpajakan, pemeriksaan pajak dan tarif pajak. Hal ini sejalan dengan teori kriminologi ekonomi, ketika manusia akan bertindak berdasarkan pertimbangan untuk mendapatkan utilitas (utility theory) yang maksimal dari sumber daya yang dimiliki (Allingham \& Sandmo, 1972).

Berdasarkan penelitian Alm (2013), dapat diartikan bahwa motivasi wajib pajak melaksanakan kewajiban pajaknya, termasuk melaporkan SPT Tahunan, semata-mata karena takut akan sanksi dan denda administrasi, takut akan dilakukan pemeriksaan, dan masalah tarif pajak. Misalnya, tarif pajak akan memotivasi mereka untuk 
melakukan perencanaan pajak untuk tujuan menghindari pengenaan pajak dengan tarif tinggi, Penelitian Alm ini juga menyebutkan bahwa wajib pajak tidak selalu berperilaku dalam pandangan teori kriminoligi ekonomi di aras seperti egois, rasional, mementingkan diri sendiri, melainkan sering termotivasi oleh banyak faktor lain seperti norma-norma sosial, moralitas, altruisme, dan keadilan.

Perilaku pajak terkait dengan kepatuhan atau ketidakpatuhan antara lain adalah tidak menyampaikan surat tahunan, tidak melaporkan pendapatan dalam surat pemberitahuan tahunana, tidak melaporkan pendapatan dalam surat pemberitahuan tahunan, keterlibatan dalam shadow economy, atau tidak melaporkan biaya sesungguhnya. Cara pandang atau evaluasi wajib pajak terhadap fiskus tampak dalam dau postur motivasi yang diidentifikasi dala penelitian tersebut adalah commitment dan capitulation. Commitment adalah tingkatan ketika wajib pajak secara sadar berkeinginan atas kehendaknya sendiri untuk merasa terlibat dengan misi otoritas pajak sebagai regulator. Capitulation menggambarkan individu yang menerima berbagai aturan yang diterapkan kepadanya oleh otoritas pajak tanpa harus merasa terlibat dengan otoritas pajak.

Penelitian ini tidak hanya menguji pengaruh patriotisme terhadap kepatuhan wajib pajak namun juga menambahkan variabel lainnya yaitu commitment dan capitulation sebagai sebagian komponen dari postur motivasi. Penelitian terdahulu (Qary et al., 2009; Konrad and Qari, 2009) tidak menggunakan variabel commitment dan capitulation ketika menguji pengaruh patriotisme terhadap kepatuhan wajib pajak. Dan penelitian Mangoting dan Dardjito., 2016) tidak menguji kepatuhan wajib pajak pada usaha mikro. Penelitian ini menguji, bagaimana pengaruh patriotisme, commitment, dan capitulation terhadap wajib pajak usaha mikro dalam kewajiban penyampain SPT di Indonesia?. Berdasarkan pertanyaan penelitian tersebut, maka tujuan penelitian ini dilakukan untuk menguji pengaruh tingkat patriotisme, commitment dan capitulation terhadap kepatuhan wajib pajak.

\section{KERANGKA TEORITIS DAN PENGEMBANGAN HIPOTESIS}

\subsection{Patriotisme}

Penelitian ini menggunakan teori identitas sosial dalam menjelaskan hubungan antara patriotisme dengan kepatuhan wajib pajak. Menurut Tajfel (1978 dalam Ashford et al., 1989), identitas sosial adalah bagian dari konsep diri seseorang yang berasal dari pengetahuan mereka tentang keanggotaan dalan suatu kelompok sosial bersama dengan signifikansi dan emosional dari anggota tersebut. Identitas sosial tersebut berkaitan dengan keterlibatan, rasa peduli, dan rasa bangga dari keanggotaan seseorang dalam kelompok tersebut. Berdasarkan perspektif teori identitas sosial dijelaskan pula bahwa dalam mengekspresikan dirinya, individu akan menonjolkan identitas diri dan identitas kelompok sosial.

Teori identitas sosial memberikan berbagai prediksi terhadap konsekuensi dan loyalitas nasional (Huddy and Khatib, 2007). Pertama, identitas nasional diharapkan menjadi non ideologi yang melekatkan rasa keterikatan subjektif individu pada suatu bangsa, keduam identitas nasional yang kuat diperkitakan mampu meningkatkan keterlibatan politik. Penelitian Lovoie (2011) menegaskan individu dengan tingkat oatriotik lebih tinggi cenderung sukarela mematuhi hukum perpajakan.

\subsection{Postur Motivasi}

Pemerintah harus menyadari bahwa faktor ekonomi dalam meningkatkan kepatuhan pajak seperti tarif pajak, sanksi dan denda administrasi seharusnya tidak lagi menjadi fokus utama pemerintah untuk membuat wajib pajak. Meskipun pemerintah mempunyai legitimasi hukum untuk memaksa wajib pajak, tetapi pemerintah tidak mempunyai legimitasi psikologi, sehing ga diperlukan adanya pendekatan baru dalam rangka meningkatkan kepatuhan wajib pajak. Individu dan kelompok-kelompok-kelompok di sisi lain akan memberikan evaluasi terhadap pemerintah, atau dalam hal ini fiskus atau kinerja fiskus, yang pada akhirnya akan membentuk jarak dikutip oleh Braithwaite (2007) menyebut jarak ini sebagai jarak sosial(social distance).

Menurut Braithwaite, postur motivasi adalah sinyal sosial yang dikirim oleh individu kepada otoritas pemungut pajak sebagai alat komunikasi sosial untuk mengetahui jarak sosial antara wajib pajak dengan otoritas perpajakan, konsep jarak sosial berguna untuk menjelaskan bagaimana individuindividu menempatkan diri mereka di luar jangkauan dan pengaruh otoritas, sehingga otoritas tidak mengerti atau tidak mau mendengar tuntutan, dan akhirnya individu sebagai pembayar pajak tidak mau mendengartuntutan, dan akhirnya individu sebagai pembayar pajak tidak takut konsekuensi dari ketidakpatuhan. Semakin jauh jarak sosial menandakan bahwa peraturan-peraturan perpajakan yang dibuat belum mencerinkan keinginan individu pembayar berkaitan dengan keadilan pemungutan pajak, keadilan penetapan tarif pajak, kesederhanaan tata cara pemungutan pajak. Seperti telah disampaikan penelitian ini mengidentifikasi dua postur motivasi yang digunakan, yaitu commitment dan capitulation.

Commitment adalah cerminan keyakinan wajib pajak akan suatu sistem pajak yang dikehendaki, dan kesadaran wajib pajak bahwa ia memiliki obligasi moral untuk membayar pajak dengan benar. Capitulation (penyerahan) menggambarkan individu yang menerima fiskus sebagai pihak yang memiliki legitimasi dan menganggap bahwa fiskus akan melaksanakan berbagai aturan dengan benar. 


\subsection{Hipotesis penelitian}

Davidov (2009) menjelaskan bahwa kelekatan individu sebagai bagian dari suatu negara diekspresikan dengan rasa memiliki, cinta, loyalitas, kebanggaan, dan perlindungan terhadap kelompok tanah-airnya. Salah satu bentuk identitas sosial adalah identitas nasional (Nichener and Delamater, 1999; Bostock and Smith, 2001). Tajfel and Turner (1986) menyetakan bahwa secara umum identitas nasional menggambarkan perasaan subjektif terhadap suatu bangsa, yang pada dasarnya bersifat positif. Salah satu bentuk dari identitas nasional adalah patriotisme (Blank and Smith, 2003). Staub (1998) mengidentifikasikan patriotisme sebagai keterikatan seseorang pada kelompoknya (suku, bangsa, partai politik, dan sebagainya). Keterikatan ini meliputi kerelaan seseorang dalam mengidentifikasikan dirinya pada suatu kelompok sosial untuk selanjutnya menjadi loyal (Staub, 1998). Salah satu sikap patriotisme dalam bidang ekonomi adalah melaksanakan kewajiban membayar pajak tercantum dalam pasal 23 A UUD 1945 yang berbunyi "Pajak dan pungutan lain yang bersifat memaksa untuk keperluan negara diatur dengan Undang-Undang".

Beberapa penelitian mengenai patriotisme dan kepatuhan pajak telah dilakukan, seperti penelitian Konrad and Qari (2009) membuktikan bahwa sikap patriotisme seseorang berhubungan dengan tingkat kepatuhan pajaknya. Hal tersebut dibuktikan dengan terdukungnya hipotesis penelitian yaitu negara dengan penduduk yang memiliki sikap patriotik tinggi maka tingkat kepatuhan pajaknya juga tinggi. Pada tingkat individu, individu dengan sikap patriotik tinggi lebih jujur dalam melaporkan penghasilannya dan patuh dalam membayar pajak. Hasil penelitian tersebut membuktikan bahwa sikap patriotisme dapat mempermudah pencapaian penerimaan pajak dan meningkatkan kepatuhan. Konsisten dengan hasil tersebut, penelitian Lavoie (2011) menjelaskan bahwa semakin tinggi jiwa patriotik individu maka semakin besar kemungkinan individu tersebut berbagi nilainilai bangsanya dan mendukung tujuan bangsanya serta sukarela mematuhi peraturan pajak yang berlaku di negaranya.

Patriotisme secara langsung dapat mempengaruhi sikap kepatuhan seseorang terhadap pajak dan pada akhirnya juga meningkatkan norma-norma sosial (Lavoie, 2011). Hal tersebut dikarenakan individu dengan patriotisme yang tinggi dan kuat terhadap bangsanya diasumsikan memiliki keinginan lebih besar untuk mematuhi normanorma sosial yang berlaku. Jika membayar pajak dipandang sebagai faktor yang mendukung kesejahteraan bangsanya, maka individu dengan tingkat patriotik tinggi lebih patuh dan jujur dalam membayar pajak dibandingkan dengan individu yang tingkat patriotiknya rendah. Berdasarkan teori dan penjelasan di atas, maka hipotesis pertama penelitian ini adalah:

HI: Patriotisme berpengaruh secara positifterhadap tingkat kepatuhan wajib pajak

Kepatuhan pajak menjadi hal yang sangat penting karena berkaitan fungsi pajak bagi setiap negara yaitu sebagai sumber pembiayaan pengeluaran pembangunan sebuah negara. Pendekatan melihat kepatuhan hanya dari sisi faktor-faktor ekonomi, seperti faktor sanksi dan denda administrasi, faktor pemeriksaan pajak, dan faktor tarif pajak, merupakan penyederhanaan realitas administrasi pajak yang modern. Wajib pajak saat ini justru didorong untuk mengikuti edukasi pajak, diyakinkan untuk mau bekerjasama dengan fiskus. Wajib pajak diajak untuk meyakini bahwa reformasi pajak adalah untuk kebaikan seluruh masyarakat sekaligus diajak untuk meyakini bahwa fiskus memiliki integritas.

Tolgler and Schneider (2005) menyebutkan bahwa faktor kepatuhan wajib pajak di Austria juga dipengaruhi oleh motivasi instrinsik wajib pajak yaitu faktor moral. Berdasarkan hasil penelitian ini diperoleh informasi bahwa faktor yang mempengaruhi kepatuhan pajak adalah variabel kepercayaan atau kebanggaan yang mempengaruhi moral wajib pajak sehingga diidentifikasi sebagai faktor penentu utama yang membentuk semangat kepatuhan pajak wajib pajak Austria.

Di sisi lain wajib pajak tetap ingin memanfaatkan adanya celah dalam peraturan perpajakan yang memungkinkan pembayaran pajak yang minimal atau yang biasa disebut sebagai perencanaan pajak. Dengan demikian kepatuhan wajib pajak bukan hanya didasarkan pada faktor-faktor ekonomi tersebut, tetapi juga faktorfaktor non ekonomi, seperti faktor motivasi, norma sosial, dan etika. Salah satu faktor motivasi yang diduga berpengaruh terhadap kepatuhan wajib pajak dapat dilihat dengan mempertimbangkan postur motivasi.

Commitment menunjukkan keyakinan wajib pajak terhadap suatu sistem pajak yang dikehendaki. Dengan demikian wajib pajak secara sadar berkeinginan atas kehendaknya sendiri untuk merasa terlibat dengan misi otoritas pajak sebagai regulator. Wajib pajak merasa bahwa membayar pajak adalah hal yang benar dan ia bertanggungjawab terhadap kewajibannya dengan membayar pajak sesuai dengan perhitungan dan kondisi yang sebenarnya. Semakin baik komitmen wajib pajak, semakin patuh wajib pajak tersebut.

Feld dan Frey (2007) menambahkan bahwa sebagai warga negara yang baik, wajib pajak memiliki persepsi bahwa pemabayaran pajak merupakan kontribusi untuk kebaikan bersama (bonum commune). Wajib pajak bersedia dengan jujur mengungkapkan penghasilannya meskipun mungkin mereka tidak menerima barang publik yang ekuivalen dengan nilai pajak yang mereka setorkan.

H2: Commitment berpengaruh secara positifterhadap kepatuhan wajib pajak

Capitulation (penyerah, kepasrahan) menunjukkan bahwa wajib pajak bisa menerima fiskus sebagai pihak yang memiliki legitimasi. Wajib pajak menerima berbagai aturan yang ditetapkan, menyadari bahwa peraturan itu tidak sempurna namun bisa diterapkan dengan baik. Wajib pajak lebih in gin terlibat banyak dengan fiskus. Redistribusi pendapatan lebih dapat diterima oleh wajib pajak ketika proses politik dipersepsikan semakin 
adil sehingga hasil dari proses politik tersebut memiliki legitimasi yang baik pula, semakin tinggi capitulation wajib pajak semakin patuh pajak.

H3: Capitulation berpengaruh secara positifterhadap kepatuhan wajib pajak

\section{METODE PENELITIAN}

\subsection{Model Penelitian}

Model analisis yang digunakan dalam penelitian adalah analisis regresi berganda yang digunakan untuk melihat hubungan satu variabel dependen dan lebih dari satu variabel independen yang dapat dilihati pada Gambar 1 .

\section{Gambar 1. Model Analisis Penelitian}

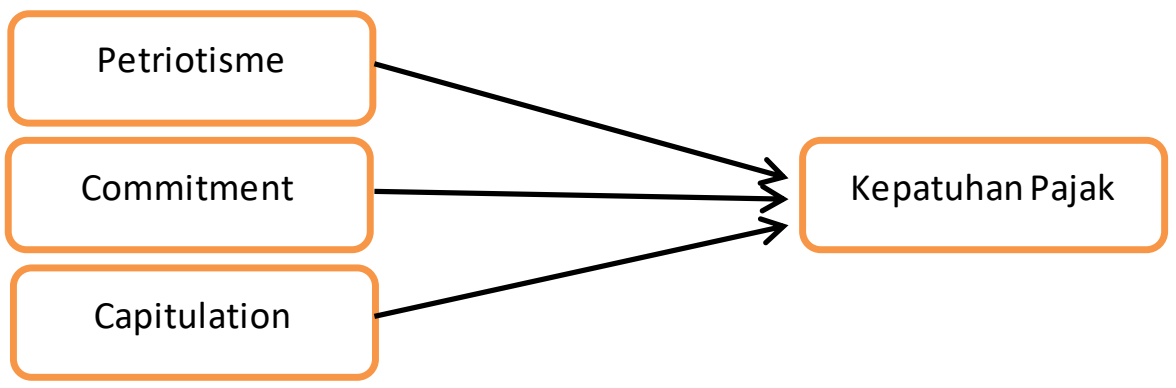

Persamaan regresi berganda berdasarkan model penelitian pada Gambar 1 adalah berikut ini:

$Y=a+b 1 X 1+b 2 X 2+b 3 X 3+e$

Keterangan:

$Y=$ Variabel tidak bebas

$a=$ konstanta

$b=$ koefisien regresi linier $\mathrm{X}$

$X 1=$ Patriotisme

$X 2=$ Commitment

$X 3=$ Capitulation

$e=$ error

Variabel independen dalam penelitian ini adalah patriotisme (PE), Commitment (CM) dan Capitulation (CP). Pertanyaan tentang patriotisme diadopsi dari penelitian Qari et al (2009), sedangkan untuk commitment dan capitulation diadopsi dari kuesioner dari penelitian Mangoting dan Sadjiarto (2016) dan Variabel dependen adalah kepatuhan wajib pajak (KWP).

Pengukuran dilakukan dengan mengajukan kuesioner kepada responden dengan beberaoa oertanyaan untuk tiap variabel independen. Skala pengukuran variabel dalam penelitian ini adalah menggunakan skala Likert. Masing-masing pen-dapat dari setiap pertanyaan diberi skor sebagai berikut: a) skor 1 untuk jawaban sangat tidak setuju, b) skor 2 untuk jawaban tidak setuju, c) skor 3 untuk jawaban netral, d) skor 4 untuk jawaban setuju, dan e) skor 5 untuk jawaban sangat setuju. Untuk variable independen, skor yang didapatkan untuk tiap pertanyaan dalam satu variabel akan dirata-rata.

Variabel dependen dalam penelitian ini terkait dengan kepatuhan (KWP), yang dijabarkan dalam 6 pernyataan. yaitu: a) Y1 adalah mengenai kepemilikan Nomor Pokok Wajib Pajak (NPWP) , b) Y2 adalah mengenai kewajiban menyetor PPh Pasal 25, c) Y3 adalah kewajiban menyetor SPT tahunan untuk orang pribadi, d) Y4 adalah NPWP usaha sama dengan NPWP pribadi, e) Y5 adalah me-laporkan SPT PPh Pasal 25, dan f) Y6 terkait kewajiban melaporkan SPT tahunan untuk wajib pajak badan. Pilihan jawaban untuk variable dependen adalah ya atau tidak. Jumlah jawaban "ya” dipakai untuk mengukur kepatuhan

\subsection{Pengumpulan Data}

Penelitian ini menggunakan data primer dalam bentuk hasil kuesioner yang dibagikan kepada responden. Metode pengumpulan data yang digunakan dalam penelitian ini menggunakan teknik kuesioner tertutup, yaitu suatu cara pengumpulan data dengan memberikan atau menyebarkan daftar pertanyaan kepada responden. Kuisioner hanya disebarkan pada Wajib Pajak Orang Pribadi yang memenuhi persyaratan minimal, yaitu: 1) mempunyai NPWP dan 2) memiliki usaha mikro, kecil atau menengah. Artinya wajib pajak orang pribadi yang bekerja sebagai karyawan tidak termasuk dalam populasi yang akan diteliti. Responden dalam penelitian ini Wajib Pajak Orang Pribadi yang memiliki usaha mikro, kecil menengah di Jakarta Utara. Penyebaran kuesioner ini dilakukan dengan cara mendatangi beberapa tempat usaha atau toko dan meminta pemilik usaha mengisinya.

\subsection{Teknik Analisis}

Sebelum menguji model dan hipotesis dalam penelitian, peneliti terlebih dahulu melakukan uji validitas dan reliabilitas atas kuesioner yang akan digunakan. Studi pilot dilakukan pada bulan januari 2017 kepada 30 
reponden wajib pajak di daerah Jakarta Utara. Hasil uji coba instrumen menunjukkan bahwa terdapat beberapa indikator yang tidak memenuhi bobot yakni, variabel patriotisme yang awalnya menggunakan 11 indikator hanya menjadi 8 indikator, variabel commitment wajib pajak yang awalnya menggunakan 6 indikator sekarang hanya menjadi 5 indikator dan variabel caputilation yang awalnya 7 indikator menjadi 5 indikator.

Deskripsi Data

Dari sejumlah 100 kuesioner yang dikembalikan oleh reponden, seluruhnya dapat digunakan untuk analis is data. Seluruh responden mengisi dengan baik dan lengkap kuesioner penelitian sehingga 100 eksemplar kuesioner yang terkumpul dapat dianalisis lebih lanjut. Berdasarkan jumlah kebutuhan data minimum untuk analis is penelitian adalah 20 (sepuluh dikalikan dengan jumlah jalur terbany ak yang mengarah pada salah satu konstruk), maka jumlah 100 eksemplar kuesioner sudah memenuhi batas minimum dan sangat mencukupi untuk penelitian ini.

Tabel 1 Gambaran Demografi Responden

\begin{tabular}{|lcc|}
\hline Jenis & $\begin{array}{l}\text { Jumlah } \\
\text { Kelamin }\end{array}$ & Orang \\
\hline Laki-laki & 54 & $54 \%$ \\
Perempuan & 46 & $46 \%$ \\
\hline Total & 100 & $100 \%$ \\
\hline
\end{tabular}

\begin{tabular}{|lcc|}
\hline Tingkat & Jumlah & Persentase \\
Pendidikan & Orang & \\
\hline SMA & 30 & $30 \%$ \\
Sarjana & 65 & $65 \%$ \\
Tidak diisi & 5 & $5 \%$ \\
\hline Total & 100 & $100 \%$ \\
\hline
\end{tabular}

Tabel 2 Gambaran Sektor Usaha Responden

\begin{tabular}{|lcc|}
\hline Sektor & Jumlah & Persentase \\
\hline Perdagangan & 50 & $50 \%$ \\
Jasa & 20 & $20 \%$ \\
Industri & 18 & $18 \%$ \\
\hline Lain-Lain & 12 & $12 \%$ \\
\hline Total & 100 & $100 \%$ \\
\hline
\end{tabular}

Tabel 3 Peredaran Usaha Responden

\begin{tabular}{|lcc|}
\hline \multicolumn{3}{|c|}{ Peredaran Usaha } \\
\hline Rupiah Per Tahun & Jumlah & Persentase \\
\hline $\begin{array}{l}\text { 0 - Rp300 juta (Usaha } \\
\text { Mikro) }\end{array}$ & 60 & $60 \%$ \\
$>\begin{array}{l}\text { Rp300 juta - Rp2,5 } \\
\text { milyar (Usaha Menengah) } \\
\text { >Rp2,5 milyar - 50 milyar } \\
\text { (Usaha Menengah) }\end{array}$ & 35 & $35 \%$ \\
\hline Total & 100 & $100 \%$ \\
\hline
\end{tabular}

\subsection{Evaluasi Model Pengukuran}

Tahapan pengevaluasian model pengukuran tersebut melalui beberapa pengujian yakni reliabilitas konsistensi internal, uji validitas konvergen dan uji validitas determinan. Hasil pengujian tersebut dapat dilihat pada tabel 4 Evaluasi model pengukuran pada variabel reflektif biasa diawali dengan reliabilitas konsistensi internal (Sholihin dan Ratmono, 2013). Parameter untuk mengukur reliabilitas konsistensi internal adalah alpha cronbach dan reliabilitas komposit. Hasil analis is menggunakan WarpPLS 3.0 menunjukkan bahwa skor alpha cronbach dan reliabilitas komposit pada semua variabel telah memenuhi syarat, yaitu >0,70. Evaluasi model pengukuran selanjutnya adalah melihat validitas konvergen dan validitas diskriminan masing-masing indikator valiabel. Validitas konvergen dievaluasi menggunakan nilai Extracted Average Variance (AVE) dengan kriteria nilai AVE harus di atas 0.50. Sedangkan Validitas diskriminan menggunakan kriteria akar kuadrat AVE (kolom diagonal) yang harus lebih tinggi dari korelasi antar variabel laten pada kolom yang sama (di atas atau di bawahnya). Hasil pengujian menunjukkan bahwa validitas konvergen dan validitas diskriminan telah terpenuhi. 
Tabel 4

Koefisien Variabel Laten

\begin{tabular}{|l|c|c|c|c|}
\hline & PE & CM & CP & KWP \\
\hline R-squared coefficients & & & & 0,657 \\
\hline Composite reliability coefficient & 0,857 & 0,825 & 0,833 & 0,996 \\
\hline Cronbath's alpha coeficients & 0,086 & 0,772 & 0,081 & 0,851 \\
\hline Average variance extracted & 0,533 & 0,623 & 0,589 & 0,643 \\
\hline Full collinearity VIFs & 1,245 & 1,233 & 1,238 & 1,024 \\
\hline $\begin{array}{l}\text { Q-squared Cronbach's alpha } \\
\text { coeficients }\end{array}$ & & & & 0,677 \\
\hline
\end{tabular}

Sholihin dan Ratmono (2013) menjelaskan bahwa koefisien $R$-squared menunjukkan besaran presentasi variansi dari konstruk endogen yang dijelaskan oleh konstruk eksogen, semakin besar nilai $R$-squared menandakan bahwa semakin baik model tersebut. Model struktural dalam PLS dievaluasi dengan menggunakan $R$ Squared $\left(R^{2}\right)$ dan nilai $Q$-Squared untuk variabel dependen dan nilai koefisien pada jalur $(\beta)$ untuk variabel independen. Hasil analisis koefisien R-Squared menunjukkan bahwa variansi konstruk kepatuhan wajib pajak dapat dijelaskan sebesar 65,7\% oleh variansi konstruk eksogen. Hasil tersebut menunjukkan bahwa, variansi kepatuhan wajib pajak dapat dijelaskan sebesar 65,7\% oleh variansi patriotisme, Commitment, dan Caputilation. Koefisien $Q$-squared menjelaskan mengenai validitas prediktif (relevansi) dari beberapa konstruk eksogen terhadap konstruk endogen. Sholihin dan Ratmono (2013) menjelaskan bahwa model yang memiliki validitas prediktif harus memiliki koefisien $Q$-squared yang lebih besar dari nol. Besaran nilai $Q$-squared untuk KWP sebesar 0,677, besaran nilai koefisien tersebut menunjukkan bahwa validitas prediktif model sangat baik.

Pengujian Hipotesis Penelitian

Penelitian ini menguji 3 hipotesis. Pada bagian ini akan dibahas mengenai bagaimana hipotesis -hipotesis tersebut diuji berdasarkan data penelitian yang sudah terkumpul sebelumnya. Keterdukungan atas hipotesis hipotesis tersebut ditentukan dengan menggunakan nilai-nilai dan koefisien jalur (Path Coefficients), standard errors, effect sizes, dan $P$-value atas koefisien jalur tersebut yang tersaji pada tabel 5.

Tabel 5

Koefisien Jalur, Standards Errors, Effect Sizes, dan P-value

\begin{tabular}{|l|c|c|c|c|c|c|}
\hline KONSTRUK & SIMBOL & $\begin{array}{c}\text { Path } \\
\text { Coeficient }\end{array}$ & $\begin{array}{c}\text { Standards } \\
\text { Errors }\end{array}$ & $\begin{array}{c}\text { Effect } \\
\text { Size }\end{array}$ & $\begin{array}{c}\text { P- } \\
\text { Value }\end{array}$ & HASIL \\
\hline $\mathrm{PE}$ & + & 0,448 & 0,076 & 0,225 & 0,023 & TERDUKUNG \\
\hline $\mathrm{CM}$ & + & 0,451 & 0,068 & 0,341 & 0,033 & TERDUKUNG \\
\hline $\mathrm{CP}$ & + & 0,356 & 0,055 & 0,365 & 0,045 & TERDUKUNG \\
\hline
\end{tabular}

Berikut adalah penjelasan hasil pengujian berdasarkan masing-masing hipotesis:

HI: Patriotisme berpengaruh secara positif terhadap tingkat kepatuhan wajib pajak

Tabel 5 di atas menyajikan data hasil pengujian untuk hubungan patriotis me dengan kepatuhan wajib pajak. Pada tabel tersebut patriotisme berpengaruh positif terhadap kepatuhan wajib pajak yang ditunjukkan dengan nilai koefisien jalur sebesar 0,448 dengan p-value $<0,023$ dan memiliki effect sizes sebesar 0,225. Nilai effect sizes sebesar 0,225 tergolong medium, seperti yang dijelaskan Sholihin dan Ratmono (2013) bahwa nilai effect size terbagi menjadi 3 (tiga) yaitu lemah $(0,02)$; medium $(0,15)$; dan kuat $(0,35)$. Hasil tersebut membuktikan bahwa patriotisme berpengaruh positif terhadap kepatuhan wajib pajak dan dengan demikian hipotesis $\mathrm{H} 1$ terdukung. Hasil ini mengindikasikan bahwa peningkatan jiwa patriotisme individu akan meningkatkan kepatuhannya sebagai wajib pajak. Hasil penelitian tersebut konsisten dengan penelitian Lavoie (2011) bahwa semakin tinggi patriotik individu maka semakin besar kemungkinan individu tersebut berperan dalam mensukseskan tujuan bangsa dan secara sukarela patuh pada regulasi perpajakan yang berlaku.

Dalam motivasi psikologi sosial seperti patriotisme berperan penting dalam menumbuhkan kesadaran wajib pajak dalam mematuhi dan melaksanakan segala kewajibannya dalam upaya peran meningktakan pembangunan nasional. patriotisme menumbuhkan kerelaan wajib pajak untuk berkontribusi pada kemakmuran, kesejahteraan, kemajuan dan keberlangsungan bangsa termasuk melalui pembayaran pajak.

H2: Commitment berpengaruh secara positif terhadap kepatuhan wajib pajak

Faktor lain yang diprediksi dapat mempengaruhi kepatuhan wajib pajak adalah commitment, ditunjukkan dengan nilai koefisien jalur sebesar 0,451 dengan p-value $<0,033$ dan memiliki effect sizes sebesar 0,341. Hal ini menunjukkan bahwa commiment memberikan pengaruh yang signifikan terhadap tingkat kepatuhan wajib pajak. Dengan hasil tersebut maka $\mathrm{H} 2$ terdukung. Hasil penelitian tersebut konsisten dengan penelitian Feld and Frey (2007). Commitment menunjukkan keyakinan wajib pajak terhadap suatu sistem pajak yang dikehendaki. 
Dengan demikian peneliti menduga wajib pajak secara sadar berkeinginan atas kehendaknya sendiri untuk merasa terlibat dengan misi otoritas pajak sebagai regulator apabila sistem pajak sudah sesuai dengan yang dikehendaki akan meningkatkan kepatuhan perpajakannya.

H3: Capitulation berpengaruh secara positifterhadap kepatuhan wajib pajak

Pada tabel 5 di atas menyajikan data hasil pengujian untuk hubungan Capitulation dengan kepatuhan wajib pajak. Pada tabel tersebut capitulation berpengaruh positif terhadap kepatuhan wajib pajak yang ditunjukkan dengan nilai koefisien jalur sebesar 0,356 dengan $p$-value $<0,045$ dan memiliki effect sizes sebesar 0,365. Hal ini menunjukkan bahwa capitulation memberikan pengaruh yang signifikan terhadap tingkat kepatuhan wajib pajak. Dengan hasil tersebut maka $\mathrm{H} 2$ terdukung. Wajib pajak menerima berbagai aturan yang ditetapkan, menyadari bahwa peraturan itu tidak sempurna namun bisa diterapkan dengan baik. Peneliti menduga wajib pajak lebih ingin terlibat banyak dengan fiskus. Redistribusi pendapatan lebih dapat diterima oleh wajib pajak ketika proses politik dipersepsikan semakin adil sehingga hasil dari proses politik tersebut memiliki legitimasi yang baik pula, semakin tinggi capitulation wajib pajak semakin patuh pajak.

\section{Kesimpulan dan Saran}

Berdasarkan hasil analisis pendekatan kuantitatif diperoleh bahwa patriotisme, commitment dan capitulation berpengaruh positif terhadap kepatuhan wajib pajak. Penelitian ini membuktikan bahwa patriotisme yang dideskripsikan kecintaan wajib pajak dan jiwa nasionalisme pada negara berpengaruh positif terhadap kepatuhan wajib pajak dalam bidang perpajakan. Terimplementasinya suatu sistem yang dikehendaki oleh wajib pajak juga akan mendorong peningkatan wajib pajak dalam memenuhi kewajiban perpajakannya, hal ini dibuktikan dengan commitment berpengaruh positif terhadap kepatuhan wajib pajak. Pengakuan terhadap kewenangan fiskus sebagai pihak yang memiliki legitimasi akan mendorong persepsi positif bagi wajib pajak dalam menjalankan kewajiban perpajakannya, karena peraturan yang tidak sempurna akan tetap berjalan dengan baik apabila fiskus menjalankannya dan menerapkannya dengan baik, sehingga terciptanya motivasi kepatuhan perpajakan di masyarakat.

Pemerintah sebaiknya meningkatkan jiwa patriotisme warganya dalam upaya kehidupan berbangsa dan bernegara, hal ini dapat juga meningkatkan pendapatan negara di bidang perpajakan dikarenakan peningkatan jiwa nasionalisme berkorelasi positif terhadap kemauan wajib pajak melaksanakan kewajiban perpajakannya. Suatu sistem perpajakan juga seharusnya dibuat sesuai dengan kehendak dan memudahkan wajib pajak dalam melaksanakan kepatuhan dalam menjalankan kewajiban perpajakannya. Terkahir adalah pendekatan dan sosialisasi pihak fiskus terhadap wajib pajak harus lebih ditingkatkan, hal ini dikarenakan kepercayaan wajib pajak terhadap fiskus akan meningkatkan kemauan wajib pajak dalam memenuhi kewajibannya dalam bidang perpajakan.

\section{DAFTAR PUSTAKA}

[1] Allingham, M. G., \& Sandmo, A. (1972). Income Tax Evasion: A Theorethical Analysis. Journal of Public Economics, 1324.

[2] Alm, James., (2013). Expanding the Theory of Tax Compliance from Individual to Group Motiva-tions: Department of Economics, Tulane University New Orleans, LA.

[3] Badan Pemeriksa Keuangan. 2014. Laporan Hasil Pemeriksaan BPK RI atas Laporan Keuangan Pemerintah Pusat Tahun 2013 http://www.bpk.go.id/assets/files/lkpp/2013/lkpp_2013_1402973186.pdf. Diakses tanggal 15 Januari 2016

[4] Braithwaite, V., Murphy, K., \& Reinhart, M. (2007). Taxation Threat, Motivational Postures. and Responsive Regulation. Law and Policy, 1.

[5] Chittenden, F., \& Foster, H. (2008). Perspectives on Fair Tax. London: The Association of Chartered Certified Accountants.

[6] Davidov, Eldad. 2009. Measurement Equivalence of Nationalism and Constructive Patriotism in the ISSP: 34 Countries in a Comparative Perspective, Political Analysis: 64-82.

[7] Figueiredo, R. J.P de and Elkins, Z. 2002. An Inquiry into the Vices of In-group Pride. University of California, Berkeley.

[8] Laury, S., \& Wallace, S. (2005). Confidentiality and Taxpayer Compliance. National TaxJournal, 58, 3.

[9] Misu, N. B.-. (2011). A Review of Factors for Tax Compliance. Fascicle I. Economics and Applied Informatics, $1 / 2011$.

[10] Graff, G. De. 2007. Causes Of Corruption: Towards A Contextual Theory of Corruption, Public Administration Quarterly (Spring): 39-86.

[11] Shabbir, G and Anwar, M. 2008. Determinants of Corruption in Developing Countries, The Pakistan Development Review: 751-764.

[12] Sholihin, M and Dwi Ratmono. 2013. Analisi SEM-PLS dengan WarpPLS 3.0 Untuk Hubungan Nonlinear dalam Penelitian Sosial dan Bisnis. Andy Offset Yogyakarta.

[13] Tajfel, H., \& Turner, J. C. (1986). The social identity theory of intergroup behavior. Dalam S. Worchel \& W. Austin (Eds.), Psychology of intergroup relations (pp. 7-24). Chicago: Nels on Hall.

[14] Torgler, B., \& Schneider, F. (2005). Attitudes Towards Paying Taxes in Austria: An Empi-rical Analysis. Empirica, 32(2), 231-250. 